\title{
Dampak Psikososial Akibat Stigmatisasi pada Remaja Pelaku \\ Pemerkosaan Studi Kasus di Lapas Kelas 2B Kabupaten Banyuwangi
}

\author{
Indrawati Purbaningsih ${ }^{1^{*}}$, Suryanto ${ }^{2}$, Andik Matulessy ${ }^{3}$ \\ ${ }^{1}$ Program Studi Magister Sains Psikologi, Universitas 17 Agustus 1945 Surabaya \\ Email: aningpurba@gmail.com \\ ${ }^{2}$ Fakultas Psikologi, Universitas Airlangga, Jl. Airlangga No.4 - 6, Airlangga \\ ${ }^{3}$ Fakultas Psikologi, Universitas 17 Agustus 1945 Surabaya
}

\begin{abstract}
Abstrak
Tujuan dari penelitian ini adalah menganalisis dampak psikososial akibat stigmatisasi pada remaja pelaku pemerkosaan di Lapas Kelas 2B Kabupaten Banyuwangi. Peneliti menggunakan teori stigma sosial dari Erving Goffman dan Teori Stigma Internal digunakan untuk mengkaji studi mengenai terbentuknya stigma oleh masyarakat dan dampaknya terhadap stigma yang diberikan masyarakat kepada remaja pelaku pemerkosaan. Penelitian ini menggunakan pendekatan kualitatif dengan rancangan studi kasus, subjek penelitian adalah remaja pelaku pemerkosaan, metode pengumpulan data yang digunakan adalah observasi, wawancara dan dokumentasi. Hasil penelitian menunjukan stigma sosial dari masyarakat menimbulkan diskriminasi verbal maupun non-verbal yang akan berdampak terhadap kesejahteraan psikologis para narapidana pelaku pemerkosaan. Stigma tersebut dapat mempengaruhi perilaku dan kesejahteraan psikologis pada mereka yang terstigmatisasi, hal tersebut menjadi sumber keprihatinan dan tekanan bagi mereka yang terkena stigma karena dapat membuat mereka nantinya kesulitan dalam mendapatkan pekerjaan, sehingga membuat mereka termajinilisasi dari aspek ekonominya. Saran bagi peneliti selanjutnya dapat meneliti pengaruh stigmatatisasi sosial terhadap kesejahteraan psikologis para remaja pelaku pemerkosaan.
\end{abstract}

Kata kunci : Psikososial, Stigmatisasi, Remaja, Pelaku Pemerkosaan

\section{Pendahuluan}

Masa remaja merupakan periode terjadinya pertumbuhan dan perkembangan yang pesat baik secara fisik, psikologis, maupun intelektual (Kementerian Kesehatan Republik Indonesia, 2015). Remaja menurut WHO (2014) adalah penduduk dalam rentang usia 10-19 tahun, sedangkan menurut Kementerian Kesehatan Republik Indonesia (2014), remaja merupakan kelompok 
usia 10-18 tahun, dan menurut BKKBN (2015) remaja merupakan penduduk dengan rentang usia 10-24 tahun yang belum menikah. Masa remaja merupakan masa transisi dari anak-anak menuju dewasa yang melewati beberapa tahapan perkembangan dalam hidup seperti kematangan fisik dan seksual, tahapan menuju kemandirian sosial dan ekonomi, membangun identitas, dan akuisisi kemampuan (Lembaga Demografi FEB UI, 2017). Masa remaja sering dianggap sebagai masa yang penuh dengan badai karena pada masa tersebut seseorang mulai mencari jati diri dengan mencoba berbagai hal baru dan mengekspresikannya (Sarlita, 2018).

Proses pencarian jati diri tersebut membuat remaja memiliki rasa keingintahuan yang tinggi dan tertarik untuk mencoba berbagai hal baru. Peran orang tua dan lingkungan dapat mempengaruhi perilaku remaja. Kontrol orang tua dan keluarga yang lemah serta lingkungan sosial yang lebih mengarah pada hal negatif akan membentuk perilaku yang negatif pula pada remaja. Remaja yang telah terpapar oleh lingkungan sosial yang negatif dan kurangnya kontrol orang tua serta keluarga akan semakin mendorong remaja untuk memiliki perilaku kenakalan remaja seperti pemerkosaan (Fuadi, 2011). Pemerkosaan merupakan suatu tindakan pemaksaan hubungan seksual yang dapat berupa ancaman fisik maupun psikologis (Faturochman, 2002). Kasus pemerkosaan akan menimbulkan trauma yang cukup berat terhadap fisik maupun psikis korban, sehingga pemerkosaan ditempatkan sebagai contoh perbuatan kriminalitas yang melanggar HAM karena adanya pemposisian keunggulan diskriminasi gender (Kristiani, 2014).

Pelaku pemerkosaan biasanya dikaitkan dengan tindak pidana perkosaan dalam KUHP pasal 285 mengenai pidana perkosaan untu bersetubuh dan pasal 289 mengenai pidana perkosaan untuk berbuat cabul dengan hukuman maksimum 12 tahun penjara. Meskipun pelaku pemerkosaan telah diadili secara hukum, namun juga terdapat sanksi sosial yang diterima oleh pelaku baik secara langsung maupun tidak langsung sehingga adanya label yang melekat pada pelaku (Kristiani, 2014).

Pelaku pemerkosaan biasanya mengalami stigma yang berbeda pada lingkungan sosialnya. Akibat dari stigma dari perilaku menyimpang tersebut menyebabkan seseorang (aktor) terdiskualifikasi atau mendapatkan penolakan dari 
masyarakat (Astuti, 2016). Penolakan atau diskriminasi yang dialami beragam bentuknya baik verbal maupun non verbal, misalnya seperti adanya pemberian label negatif, mendapat pandangan kurang menyenangkan dari masyarakat, dijauhi dari masyarakat, menjadi bahan perbincangan, hingga pengusiran dari lingkungannya (Utami, 2018). Kajian mengenai kasus pemerkosaan lebih banyak membahas mengenai analisis dan dampak yang disebabkan pemerkosaan pada korban, namun belum banyak kajian yang membahas mengenai pelaku pemerkosaan. Berdasarkan latar belakang diatas peneliti tertarik untuk meneliti lebih lanjut mengenai dampak psikososial pada remaja yang menjadi pelaku pemerkosaan di Lapas kelas 2B Kabupaten Banyuwangi.

\section{Metode Penelitian}

Penelitian ini termasuk penelitian kualitatif deskriptif karena penelitian ini bertujuan untuk menggali dan mengkaji hal-hal mengenai stigma sosial yang dialami oleh pelaku pemerkosaan secara deskriptif. Metode Kualitatif memperlakukan teori dan metode sebagai isu yang tidak dapat dipisahkan, maka metode tidak hanya penting dalam menuntun bagaimana data dikumpulkan tetapi juga terhadap bagaimana data hendak dianalisis (Astuti, 2016).

Rancang bangun yang digunakan dalam penelitian ini adalah rancangan studi kasus. Pencarian partisipan dilakukan dengan menggunakan teknik purposive sampling yaitu informan dipilih karena memiliki kesesuaian dengan kriteria yang telah ditentukan. Adapaun informan dalam penelitian ini terdiri dari 4 orang remaja laki-laki pelaku pemerkosaan dan 2 petugas Lapas. Metode pengumpulan data yang digunakan adalah observasi, wawancara semi tertruktur dan dokumentasi. Dalam upaya memperoleh data peneliti memilih wawancara mendalam atau indepthinterview sebagai teknik pengumpulkan data, yang dilakukan pada tanggal 15 Mei 2019 di Kelas 2B Lapas Kabupaten Banyuwangi. 


\section{Hasil}

Dalam menganalisis dampak psikososial pada remaja pelaku pemerkosaan ini penulis menggunakan teori stigma sosial dari Goffman (1963) digunakan untuk mengkaji studi mengenai terbentuknya stigma oleh masyarakat dan dampaknya terhadap stigma yang diberikan masyarakat kepada remaja pelaku pemerkosaan (Astuti, 2016). Informan terdiri dari 4 remaja laki-laki pelaku pemerkosaan dan 2 petugas Lapas. Dari hasil wawancara dan observasi yang telah dilakukan peneliti, terdapat 2 faktor penyebab terjadinya kasus pemerkosaan yang sesuai apabila diamati dari ketiga faktor penyebab pemerkosaan menurut Fuadi (2011), yang akan dijelaskan sebagai berikut :

\section{Faktor kelalaian orang tua}

Kelalaian ornag tua yang tidak memperhatikan tumbuh kembang dan pergaulan anak. Perlu adanya perhatian orang tua atas maraknya kejahatan seksual yang terjadi saat ini. Jika anak bergaul tanpa pengawasan orantua bukan tidak mungkin mereka salah memilih teman, seperti keterangan informan selaku narapidana, yang memberikan keterangan bahwa "Ikut-ikutan temen. Yang bawa korbannya saya itu teman saya. Padahal sebenernya saya nggak kenal sama korbannya saya, diakan pacarnya temen saya. Saya nggak tau, diundanglah mau diajak jalan2. disuruh kerumahnya. Nah saya datang udah ada korbannya, kan saya nggak kenal. Minum-minuman itu. Itu yang berbuat temennya saya, saya belum sampe ikutan." (Informan 2, Narapidana 19 Tahun).

Berdasarkan keterangan informan 2 tersebut diperoleh data bahwa sebenarnya dirinya tidak melakukan kejahatan seksual apapun, dirinya hanya diundang teman-temanya untuk mabuk-mabukan disalah rumah temanya dan ketika dalam keadaan mabuk dirinya merasa disangkut pautkan dengan kejadian tersebut. Yang memberikan keterangan "Ndak, belum sempet (memperkosa). Kan saya kecakot temen2“. Hal tersebut sesuai dengan pernyataan Sarlita (2018) yang menyatakan bahwa lingkungan sekitar dan 
teman sebaya yang cenderung negatif dapat memberikan pengaruh negatif pada perilaku remaja.

Kemudian diperoleh juga data dari keterangan informan 3 yang merupakan narapidana berusia 20 Tahun, dirinya menuturkan bahwa "saya sebenernya gak niat melakukan itu, karena penasaran dan mabuk akhirnya berani berbuat itu karena semuanya (teman) berani mencoba (memperkosa) akhirnya ikut". Berdasarkan kedua keterangan informan diperoleh fakta bahwa pergaulan yang salah memang dapat menjerumuskan anak kedalam perilaku yang salah ataupun menyimpang, karena mereka cenderung melakukan sesuatu tanpa berfikir 2 kali dan juga terdorong rasa penasaran serta konformitas akibat ikutikutan temanya. Hal tersebut sejalan dengan pernyataan Fuadi (2011) yang menyatakan bahwa faktor pergaulan sangat berpengaruh dalam pembentukan kepribadian pada remaja, pergaulan yang salah dapat membentuk mental kepribadian yang kurang baik.

2. Faktor rendahnya moralitas dan mentalitas Pelaku

Rendahnya moralitas perilaku seperti kurangnya memiliki adab dan etika dalam berinteraksi dengan lingkungan sosialnya maupun lawan jenisnya dapat membuat seseorang tergoda kedalam perilaku seksual yang menyalahi aturan hukum maupun agamanya, seperti rendahnya ketaatan beragama yang membuat seseorang tergoda melakukan hubungan seksual diluar nikah. Berdasarkan keterangan informan 1 berusia 19 Tahun didapatkan keterangan sebagai berikut "awalnya saya pacaran selama 8 bulan, kita backstreet. Jadi orang tua saya menyetujui, tapi orangtuanya masih mempertahankan generasi chinesenya, sedangkan saya kan jawa. Jadi seakan-akan keluarganya itu ndak mau kalau saya yang jadi pacarnya si cewek itu. Tapi si ceweknya terus mempertahankan. Jadi sampai dia kuliah di Surabaya, terus disuruh mampir ke Surabaya, jadi 3 hari saya nginep di Surabaya bareng dia. Keluarganya dari Kediri datang ke Surabaya terus ketahuan dari hapenya. Jadi dari hapenya itu ketahuan kalo ada saya di hotel jadi laporin. Cuma saya itu foto aja, fotonya juga nggak fulgar, Cuma foto selfie biasa". Dirinya juga menambahkan 
"Melakukannya itu suka sama suka dan itu dipertanyakan di persidangan didepan jaksa itu juga tidak ada paksaan ataupun dimabukkan segala macem gak ada. Dia mengakui sendiri kalau melakukannya dengan suka sama suka".

Begitu juga dengan keterangan informan 3 yang memberi keterangan bahwa "ya karena dulu khilaf, nafsu naik, gak mikir panjang apalagi mikir dosa". Berdasarkan beberapa keterangan informan diatas menunjukan bahwa kurangnya moralitas dan juga mentalitas yang ada pada pelaku dapat memicu terjadinya perlakuan perkosaan maupun hubungan seksual diluar nikah. Hal tersebut sesuai dengan pernyataan Sarlita (2018), yang menyatakan bahwa meskipun terdapat kesempatan apabila pelaku dapat mengendalikan hasrat seksualnya maka kasus pelecehan seksual dan pemerkosaan tidak akan terjadi, rendahnya pengetahuan mengenai pendidikan kesehatan remaja dan pendidikan agama semakin meingkatkan parilaku menyimpang pada remaja.

\section{Diskusi}

Stigma Masyarakat pada Pelaku Perkosaan

Pelabelan atau stigma dan prasangka terhadap individu atau kelompok muncul dalam bentuk tindakan dan perlakuan yang berbeda atau bahkan tidak adil terhadap orang yang telah terstigma tersebut. Perlu kita ketahui bahwa tidak semua masyarakat memberikan empati pada korban meskipun masyarakat mengutuk tindakan pelaku. Konsep stigma dalam penelitian ini dimana korban dan pelaku banyak di dasari oleh perasaan suka sama suka. Hal tersebut di dapatkan berdasarkan keterangan dari ke empat informan yang menyatakan bahwa dirinya senang dengan adanya wawancara karena mewakili beberapa teman-temannya. "Saya kalo diwawancara gini suka, setidaknya saya bisa mewakili suara orang-orang di dalam. Kadangkan orang berfikir kok kita merasa nggak adil. Orang melakukan seperti itukan karena ya kalau memang itu murni, katakanlah memang kita bersetubuh dengan anak kecil. Kalau memang seperti itu mungkin orang dikatakan itu (pemerkosa) juga normal, tapi kalau kita kan disisilain sudah menunjukkan kalo kita pacaran gitu. Jadi kenapa dipermasalahkan? Cuma mungkin karena ada salah 
satu pihak yang ndak suka." Dirinya menambahkan "Penilaiannya sebenernya bukan pemerkosaan. Tapi yang diibaratkan namanya kayak (perkosaan), pasalnya kan namanya pelecehan anak dibawah umur. Kalau pelecehan anak dibawah umur itu biasanya orang mandangnya kita itu rendah, kalo kita nggak normal seperti itu. Kadang kita kalau ditanyain orang kita direndahkan, jadi seakan-akan (memperkosa) kita juga bisa membela diri, meskipun mider juga".

Begitu juga dengan keterangan informan 3 yang menyebutkan bahwa dirinya hanya disangkut pautkan oleh teman-temanya meskipun tidak memperkosa, "ya saya belum (tidak memperkosa). Ya saya melihat (teman-teman memperkosa)". Menurut keterangannya pihak perempuan sama sekali tidak melawan ketika pemerkosaan terjadi (karena pacar salah satu temanya). dirinya juga menganggap bahwa setelah kejadian itu merasa dikucilkan oleh tetangga dan saudaranya "Ya semua orang menilai saya ini jeleklah kaya orang rumah (tetangga), thulik tambeng katanya".

Berdasarkan keterangan beberapa informan tersebut, menurut penulis stigma sosial atau pelabelan yang didapat pelaku muncul akibat ketidaktahuan masyarakat berdasarkan kronologi yang ada, akan tetapi muncul dari penilaian yang diambil oleh putusan hakim bahwa pelaku melanggar tindak pidana pelecehan seksual di bawah umur meskipun menurut keterangan suka sama suka namun pihak orangtua perempuan merasa tidak terima. Hal tersebut sesuai dengan teori Goffman yang menggolongkan stigma sosial dalam jenis Blesmishes of Individual Character yaitu stigma yang berhubungan dengan kerusakan karakter individu, penolakan tersebut terjadi karena memiliki kepribadian yang dianggap tidak normal, sakit, memiliki kelainan dari kebanyakan orang lainnya. Stigma tipe ini sering kali mendapat perlakuan yang tidak menyenangkan dan tidak dihormati dari orang disekitarnya, seperti orang yang mengalami keterbelakangan mental (retardasi mental), narapidana, pecandu obat-obatan terlarang, koruptor, pelaku pelecehan/ pemerkosaan, homoseksialitas, pemabuk dan lain sebagainya (Utami, 2018). 
Konsep stigma dalam temuan data penelitian ini, menunjukan pelaku perkosaan menerima beberapa bentuk stigma dari masyarakat disekitarnya. Bentuk bentuk stigma yang diterima tersebut tidak hanya dalam bentuk verbal misalnya seperti panggilan nama dibubuhi istilah "penghancur masa depan anak orang", "calon bajingan", "thulik tambeng", "thulik mbenu" sampai dalam bentuk stigma non verbal misalnya mendapatkan penolakan dari kelompok masyarakat tertentu dan mendapatkan pandangan yang kurang menyenangkan dari orang lain serta sampai dijauhi teman-teman sebayanya, bahkan menurut keterangan beberapa informan pelabelan tersebut tidak hanya diberikan kepada pelaku tetapi juga orangtua dan anggota keluarganya. Stigma verbal yang pernah didapatkan oleh pelaku perkosaanakan terus berlanjut ketika banyak orang yang menyetujui bahwa stigma tersebut memang layak diberikan untuk seseorang yang dicap pelaku.

Berdasarkan keterangan Sipir Lapas beliau menyatakan "sebenarnya mereka ini kebanyakan bukan menjalani hukuman karena kasus pemerkosaan seperti yang dibicarakan orang, tetapi tindak pidana pelecehan seksual karena korbanya di bawah umur dan orangtuanya yang tidak terima meskipun suka sama suka". Beliau menambahkan "di sini ada tradisi namanya kawin colong, ya dulu sering ada yang nikah karena suka sama suka meskipun orangtuanya gak setuju ya tetep di nikahkan oleh colok (pemangku adat/ pemuka agama setempat), dan itu sah, ya tapi karena sekarang dilindungi hukum ya dilaporkan dan dapat dijerat pidana, kalau kami yang asli Banyuwangi ya tau tradisi itu tapi orang luar ya pasti gak terima kalau anaknya tiba-tiba dinikahkan oleh colok, ya mungkin mereka menganggap bahwa jika sudah melakukan hal (berhubungan seksual) itu akan direstui".

Berdasarkan hal tersebut penulis berpendapat bahwa stigma tersebut diberikan masyarakat kepada para pelaku perkosaan adalah stigma sosial yang berupa tindakan verbal maupun non verbal yang merendahkan mereka maupun anggota keluarganya karena pelaku diberikan pelabelan sebagai sesorang yang nakal dan tidak memiliki budi pekerti yang luhur karena perilakunya. 
PSISULA: Prosiding Berkala Psikologi

Vol. 1, 2019

E-ISSN: 2715-002X

Dampak Psikososial Pelaku Perkosaan

Hasil temuan analisis diatas memberikan informasi bahwa dampak stigma sosial seperti perlakuan berbeda secara verbal maupun non verbal yang diterima oleh pelaku perkosaan dan keluarganya tersebut akan menimbulkan perlakuan yang berbeda pula. Perlakuan yang berbeda ini yang akan menimbulkan perilaku diskriminatif, dimana sering kali ditandai dengan perlakuan yang tidak adil dan sering kali juga mendapatkan perlakukan negatif dari orang lain.

Hal tersebut sesuai dengan teori menurut Link dan Phelan (dalam Scheid \& Brown, 2010) yang mengacu pada pemikiran Goffman (1963) bahwa komponen stigma sosial terdiri dari labeling, streotipe, separation dan juga diskriminasi. Masyarakat memberikan perilaku diskriminatif karena adanya stigma yang telah dipercaya oleh sebagian besar masyarakat bahwa seseorang yang sudah nakal atau "thulik tambeng" akan tetap nakal dan tidak bisa diperbaiki lagi. Sikap penolakan masyarakat seperti inilah yang disebut perilaku diskriminatif dalam aspek sosialisasi kepada pelaku perkosaan tersebut. Sedangkan dari dari argumen beberapa informan tersebut menunjukkan suatu bentuk perlakuaan diskriminatif dapat membuat mereka nantinya kesulitan dalam hal ekonomi, dimana kesempatan para pelaku perkosaan untuk mendapatkan pekerjaan semakin sempit, dengan kondisi yang serba kekurangan dan lapangan pekerjaan yang juga semakin sempit membuat mereka semakin termajinilisasi dari aspek ekonominya. Sehingga penulis mengambil kesimpulan bahwa mereka yang mendapat stima sosial di masyarakat akan berdampak terhadap kesejahteraan psikologis pada narapidana pelaku pemerkosaan karena mereka selalu merasa cemas akan kehidupan masa depanya.

Temuan ini menguatkan hasil penelitian yang dilakukan oleh Ariantini (2013) menunjukkan bahwa terdapat hubungan positif antara dukungan sosial dengan kesejahteraan psikologis, yaitu semakin tinggi dukungan sosial yang diberikan akan meningkatkan kesejahteraan psikologis seseorang. Hal tersebut juga sejalan dengan penelitian yang dilakukan oleh Utami (2018) yang menyatakan bahwa 
semakin tinggi stigma sosial yang diterima akan menurunkan kesejahteraan psikologis pada narapidana.

\section{Kesimpulan}

Berdasarkan analisis temuan data yang diperoleh dari proses analitis teoritis yang dilakukan, menunjukan bahwa pelaku perkosaan menerima beberapa bentuk stigma dari masyarakat disekitarnya. Bentuk stigma yang diterima tersebut tidak hanya dalam bentuk verbal seperti panggilan nama dibubuhi istilah "calon bajingan", "thulik tambeng", "thulik mbenu" sampai dalam bentuk stigma non verbal misalnya mendapatkan penolakan dari kelompok masyarakat tertentu dan mendapatkan pandangan yang kurang menyenangkan dari orang lain serta sampai dijauhi teman-teman sebayanya, bahkan pelabelan tersebut tidak hanya diberikan kepada pelaku tetapi juga orangtu dan anggota keluarganya.

Adapun temuan lain yang mengacu pada keterangan beberapa petugas Lapas bahwa terdapat tradisi kawin colong yang ada di Banyuwangi, dimana hal tersebut dianggap wajar dizaman dahulu dan tidak dapat ditindak pidanakan seperti saat ini meskipun sifatnya memaksa pihak keluarga perempuan untuk menikah karena alasan laki-laki dan perempuan saling menyukai. Akan tetapi, dengan minimnya pengetahuan remaja tersebut tentang perlindungan hukum anak di bawah umur, membuat mereka salah mengambil keputusan dalam bertindak sehingga melebihi batas wajar dalam melakukan hubungan asmara di usianya. Terlepas dari hal tersebut, hasil temuan penulis memberikan informasi bahwa dampak stigma sosial akan menimbulkan perlakuan yang berbeda seperti diskriminatif, dimana sering kali ditandai dengan perlakuan yang tidak adil dan sering kali mendapatkan perlakukan negatif.

Sehingga penulis mengambil kesimpulan bahwa pelaku pemerkosaan yang mendapat stima sosial di masyarakat akan berdampak terhadap kesejahteraan psikologis mereka, hal tersebut menjadi sumber keprihatinan dan tekanan bagi mereka yang terkena stigma karena dapat membuat mereka nantinya kesulitan dalam hal ekonomi, 
dimana kesempatan para pelaku perkosaan untuk mendapatkan pekerjaan semakin sempit, sehingga membuat mereka semakin termajinilisasi dari aspek ekonominya.

\section{Daftar Pustaka}

Astuti, I. S. Y., 2016. Interaksi Sosial Korban Pemerkosaan di Kabupaten Tuban.

Chaudhury, S., Bakhla, A. K., Murthy, P. \& Jagtap, B., 2017. Psycological Aspacts of Rape ans Its Consequences. Psycology and Behavioral Science International Journal. 2(3), pp. 001-007.

Farhani, M., 2017. Analisis Penyebab Penyimpangan Perilaku Seksual pada Pelaku Pelecehan dan Pemerkosaan pada Remaja. [Online] Available at: https://core.ac.uk/download/pdf/141857634.pdf [Accessed 1 July 2019].

Faturochman, E. M., 2002. Pemerkosaan, Dampak, dan Alternatif Penyembuhannya. Jurnal Prikologi. Volume 1, pp. 1-18.

Fuadi, M. A., 2011. Dinamika Psikologis Kekerasan Seksual: Sebuah Studi Fenomenologi. Psikoislamika, 8(2), pp. 191-208.

Goffman, E., 1963. Stigma: Noters on the Management of Spoiled Identity. New York: Prentice-Hall.

Kementerian Kesehatan Republik Indonesia, 2014. Peraturan Menteri Kesehtaan Republik Indonesia Nomor 25 tahun 2014 tentang Upaya Kesehatan Anak, Jakarta: Kementerian Kesehatan Republik Indonesia.

Kristiani, N. M. D., 2014. Kejahatan Kekerasan Seksual (Pemerkosaan) Ditinjau dari Perspektif Kriminologi. Jurnal Magister Hukum Udayana. 7(3), pp. 371-382.

Lembaga Demografi FEB UI, 2017. Prioritaskan Kesehatan Reproduksi Remaja Untuk Menikmati Bonus Demografi. Jakarta: Lembaga Demografi FEB UI.

Major, B., \& O'Brien, L.T. 2005. The social psychology of stigma. Annual Review of psychology 56 (1):393- 421

Sarlita, B. P., 2018. Perilaku Pekosaan pada Remaja. [Online] Available at: eprints.ums.ac.id/63560/11/NASKAH\%20PUBLIKASI-436.pdf [Accessed 1706 2019].

Tobing, D. H. et al., 2016. USDI (Unit Sumber Daya Informasi). [Online] Available at: 
PSISULA: Prosiding Berkala Psikologi

Vol. 1, 2019

E-ISSN: 2715-002X

https://simdos.unud.ac.id/uploads/file_pendidikan_1_dir/aa3b2a6d950ec00 4f20028ef8459ea8c.pdf [Accessed 2 Juli 2019].

Utami, Wahyu. 2018. Pengaruh Persepsi Stigma Sosial Dan Dukungan Sosial Terhadap Kesejahteraan Psikologis Pada Narapidana. Journal An-nafs. Vol. 3 No. 2 | 183

Vogel, D.L, N.G. Wade \& S. Haake, (2006). Measuring the self stigma associated with seeking psychological help. J. Counsel. Psychology., (53) 325-337. 